\title{
GESTOS E RESISTÊNCIA: IMAGEM E MONTAGEM DO PENSAMENTO
}

\author{
Elisandro RODRIGUES ${ }^{1}$ \\ Luciano Bedin DA COSTA ${ }^{2}$
}

\begin{abstract}
Resumo
Nos últimos oito anos, desde 2009, o mundo vem presenciando ondas crescentes de levantes populares que têm sacudido, em seus agires micropolíticos, algumas estruturas. Protestos, manifestações, marchas e ocupações que, de diferentes recantos, insurgem enquanto remontagens do sujeito em sua dimensão coletiva. Este ensaio encontra em Didi-Huberman, mais especificamente em sua exposição Soulevements (Levantes), elementos para pensar conceitualmente a montagem sacudida pelos acontecimentos políticos atuais. Didi-Huberman monta essa exposição pensando em cinco tempos, cinco gestos que vão do micro ao macro, a saber: o gesto da fúria inquieta, o gesto intensivo de um corpo que grita, o gesto de clamor da palavra, o gesto de inflamação coletiva dos vagalumes e o gesto de sobrevivência para além do seu desaparecimento. Através de algumas imagens da exposição e da obra "Carta ao Pai", de Elida Tessler, traça-se alguns elementos para pensar a montagem como modo de expor visualmente as descontinuidades do tempo que atuam em todas as sequências da história, modos de organizar - de desmontar, de analisar e também de contestar - o próprio horizonte de nosso tempo. Por fim, com subsídio de Dardot, Laval, Negri e Hardt, chega-se à ideia de desmontagem do neossujeito, deste sujeito contemporâneo e neoliberal do qual o desejo é tomado como um novo poder, espaço ininterrupto de disputa. No entanto, a produção de um comum - resgatada pelo drapeado dos levantes atuais - é aqui evocada enquanto gesto efetivo de resistência.
\end{abstract}

Palavras-Chave:Montagem; Levantes; Gesto; Resistência, Comum.

\begin{abstract}
For the last eight years, since 2009, the world has been witnessing crescent waves of popular uprisings that have been shaking some structures within its micropolitical actions. Protests, manifestations, marches and occupations, from different corners, thatrise against while reassemblies of the subject in its collective dimension. This essay finds in Didi-Huberman, more specifically in his exposition Soulevements (Uprisings), elements to conceptually think the montage shaken by the current political events. Didi-Huberman installs this exposition thinking about five times, five gestures, from micro to macro, namely: the gesture of the restless fury, the intensive gesture of a body that screams, the gesture of clamor of the word, the gesture of the collective inflammation of fireflies and the gesture of survival beyond its fade. Through some images of the exposition and the work "Carta ao Pai", from Elida Tessler, some elementsare sketched to think the montage as way of visually expose the discontinuities of time that act in all history sequences, manners to organize - to dismount, to analyze and also to contest - the own horizon of our time. Lastly, with subsidies from Dardot, Laval, Negri e Hardt, it comes to the idea of disassembly of the neo-subject, this contemporary and neoliberal subject of which the desire is taken as a new power, uninterrupted space of dispute. However, the production of a common - rescued by the drape of the current uprisings - it is here evoked whereas an effective gesture of resistance.
\end{abstract}

Keywords: Montage; Uprisings; Gesture; Resistance, Common.

\footnotetext{
1 Doutorando em Educação Unisinos, Apoiador Pedagógico da Residência Multiprofissional em Saúde, Gerência de Ensino e Pesquisa (GEP), Grupo Hospitalar Conceição (GHC). E-mail: elisandromosaico@gmail.com

2 Docente da Faculdade de Educação e Programa de Pós-Graduação em Psicologia Social e Institucional da Universidade Federal do Rio Grande do Sul - UFRGS. E-mail: bedin.costa@gmail.com
} 


\section{Resumen}

En los últimos ocho años, desde el 2009, el mundo ha visto crecientes olas de movidas populares que han estremecido algunas estructuras con sus actuaciones micro políticas. Protestos, manifestaciones, marchas y ocupaciones que, desde diferentes rincones, insurreccionan como nuevos montajes del sujeto en su dimensión colectiva. Este ensayo encuentra en Didi-HUberman en su exposición Soulevements (Movidas) elementos para pensar conceptualmente el montaje, que ha estremecido por los acontecimientos políticos actuales. Didi-Huberman monta esa exposición pensando en cinco tiempos, cinco gestos que van del micro al macro, siendo ellos: el gesto de la furia inquieta; el gesto intensivo de un cuerpo que grita; el gesto de clamor de la palabra; el gesto de inflamación colectica de las luciérnagas y el gesto de sobrevivencia más allá de su desaparecimiento. A través de algunas imágenes de la exposición juntamente con la obra "Carta al padre" de Elida Tessler, algunos elementos se plantean para pensar el montaje como modo de exponer visualmente las discontinuidades del tiempo, las cuales actúan en todas las secuencias de la historia, modos de organizar -desmontar, analizar, y también contestarel propio horizonte de nuestro tiempo. Finalmente, con la ayuda de Dardot, Laval, Negri y Hardt se llega a la idea de desmontaje del neo sujeto, este sujeto contemporáneo y neoliberal que se toma el deseo como nuevo poder, espacio ininterrumpo de disputa. Sin embargo, la producción de un común -rescatado por el drapeado de las movidas actuales- es evocada en cuanto gesto efectivo de resistencia.

Palabras clave: Montaje, Movida, Gesto, Resistencia, Común.

O exame pericial que o olho realiza é sempre pobre e incerto. Quem vem enriquecer esta pobreza imaginativa do olho é a imaginação, mistura poderosa de experiência, invenção e sonho. Waly Salomão (2005, p.105).

Não sabemos o que pode uma imagem. Algumas nos deixam completamente idiotas, outras parecem despertar a vida do espírito deixando passar como um sopro que move o pensamento e o obriga a interrogar as potências da luz e da desordem. Georges Didi-Huberman (2006, p. 01).

\section{DE UM OUTRORA-AGORA}

“Para saber é preciso imaginar", é o que comenta Didi-Huberman (2012, p. 15-49) ao pensar a imagem apesar de tudo. Para ele a imaginação é uma imagem lacuna (DIDIHUBERMAN, 2012) que pode ser potencializada pelas experiências cotidianas. Então imaginemos, em um exercício de pensar a imagem e a montagem do pensamento, e também para que a imagem nos pense.

Se Deleuze, Foucault, Barthes, Guattari, entre tantos outros autores dos quais gostamos, fossem vivos hoje estivessem de passagem pelo Brasil - ou aqueles que estão vivos e que não vivem por aqui, como Agamben, Negri e o próprio Didi-Huberman, poderíamos imaginar que, em certo momento dessa visita, poderiam estar presentes nas manifestações e ocupações atuais. E, abrindo nosso campo de ficções, pensemos esses nossos 
estimados autores, munidos de sprays e canetões, grafando com os próprios punhos, e com tintas de várias cores, em alguma parede que acolhesse suas escritas, um "Fora Temer".

Dado o contexto atual não poderíamos iniciar esse ensaio de outro modo. Nos últimos oito anos, desde 2009, o mundo vem presenciando ondas crescentes de manifestações, de movimentos, de revoltas, agitações populares, de levantes que tem sacudido, no seu fazer micropolítico, algumas estruturas. Devires-Minoritários, ou como diriam Deleuze e Guattari, devires-revolucionários, que sempre estiveram presentes na nossa história e que, por conexão e contágio, acabam por nos lembrar que os acontecimentos e insurreições nunca se dão de forma isolada ou endógena. É o caso de maio de 68, lembrado por Rita Veloso (2017, p.57):

Era um tempo de "reviravolta do mundo revirado", em que sucediam-se os protestos: Berlim oriental, 1953; Revolução na Hungria, 1956; protestos em Berkeley, 1964; movimento estudantil em Berlim Ocidental, 1967; as ocupações de fábrica em Turim, 1967; o fechamento das universidades na Itália, 1968; Primavera de Praga, 1967; rebeliões em Strassburgo, dezembro de 1966; os enragés em Nanterre, América Latina, fevereiro de 1968; e, finalmente, ocupação da universidade de Sorbonne, em maio de 1968.

Os levantes, sublevações, protestos, ocupações, marchas, insurreições de hoje são fragmentos utópicos, são remontagens de um tempo, anacronismos históricos. Barricadas e mãos erguidas como criação de um intervalo utópico, como uma pequena obstrução do real.

O que se passa nas barricadas em Paris no século XIX, novamente se dá - ao modo de uma reativação da ira e dos desejos reprimidos daquelas populações - em maio de 1968, nos 18 dias do acampamentos na praça Tahrir na cidade do Cairo, nos protestos no parque Gezi em Istambul, nos ataques da polícia munida de gás aos manifestantes de junho de 2013 no Rio de Janeiro, pode ser descrito como aqueles momentos decisivos da história em que se dá uma interrupção libertadora do curso das coisas. (VELLOSO, 2017, p. 49).

Em 2009 estudantes da Universidade da Califórnia ocuparam os prédios em protestos contra os cortes no orçamento da educação. No dia 20 de Novembro de 2009 foram presos ao tentarem ocupar o campus de Berkeley. Em uma faixa lia-se "Occupy everything" (Ocupe tudo).

Hardt e Negri (2014, p. 10) comentam que o ano de 2011 começou cedo. "Em 17 de dezembro de 2010, em Sidi Bouzid, na Tunísia, Mohamed Bouazizi, vendedor ambulante [...] se autoimolou. No final de dezembro, a revolta popular tomou conta de Túnis”. Iniciou-se uma onda de levantes, contra os regimes opressivos, que se espalhou por outros países, a Primavera Árabe. Tunísia 18 do dezembro de 2010. Argélia 29 de dezembro de 2010. 
Jordânia, Omã, Egito, Iêmen, Arábia Saudita, Síria, entre outros países iniciaram nos anos seguintes seus levantes. Em 2011 na Espanha, através das redes sociais brotava pelo meio o 15-M, o movimento dos indignados. Em setembro de 2011, no coração econômico dos Estados Unidos, Occupy Wall Street. De setembro a outubro de 2011 movimentos de resistência ocuparam mais de 95 cidades em 82 países. Um slogan, ou uma imagem em comum, "Nós somos os 99\%".

\begin{abstract}
Os protestos contra os regimes repressivos se espalharam rapidamente para outros países do Norte da África e do Oriente Médio, incluindo Bahrein e Iêmen e, pouco depois, Líbia e Síria, mas a fagulha inicial na Tunísia e no Egito também acendeu o fogo em lugares mais distantes. Os manifestantes que ocuparam a sede do Poder Legislativo de Wisconsin, em fevereiro e março de 2011, expressariam solidariedade aos seus pares do Cairo e reconheceram seu eco, mas o passo decisivo começou com o 15 de maio, nas ocupações centrais de Madri e Barcelona pelos indignados. (HARDT; NEGRI, 2014, p. 11).
\end{abstract}

Algumas cidades no Brasil aderiram ao movimento dos Occupys em 2011. Em 2012, no Rio + 20 houveram manifestações e ocupações. Em 2013 as jornadas de junho, ou manifestações de junho, mais recentes em nossa memória. Entre as bandeiras de luta, uma imagem, "não é por 20 centavos". Em 2014, 2015 e 2016 as manifestações continuaram, cresceram, perderam forças, voltaram: não vai ter Copa; pró e contra impeachment; Olimpíadas; Fora Temer; Escolas e universidades ocupadas, Contra PEC 55/241, Contra Reforma do Ensino Médio, Escola Sem Partido.

Negri e Hardt comentam que essas lutas são lutas pelo comum "no sentido de que contestam as injustiças do neoliberalismo e, em última análise, a regra da propriedade privada" (2014, p. 15). Lutas pelo comum que produzem outras subjetividades, outros modos de viver a vida, para Bauman (2016, p. 37) são modos de experimentar a vida, "as pessoas vão para as ruas numa viagem de descoberta e de turnos de experimentação". São laboratórios "em que maneiras de confrontar esses desafios", da produção de um comum, "e atacar esses problemas são esboçadas, debatidas e testadas na prática, em base diária”.

\title{
2. SOULEVEMENTS E IMAGENS DE RESISTÊNCIA.
}

Para Gilles Deleuze (2001) a criação é um ato, um gesto, uma forma de resistência, “criar é resistir", diz ele. Os levantes, manifestações e ocupações são processos de resistência. Um gesto de criação de resistências moleculares, máquinas de resistência, micropolíticas de 
resistência que tentam libertar a vida dos homens. São faíscas de um possível, são processos utópicos como um abrir frestas. Como possibilidades utópicas de imaginação e de criação. Georges Didi-Huberman (2011) chama essas resistências de imagens-lampejo, imagensVagalumes. Imagens que fazem furo no escuro que vivemos.

Chegamos, nesse ensaio, ao pensamento de Didi-Huberman e a exposição Soulevements, que tem sua curadoria. Ocorrida no Jeu de Paume, em Paris, entre outubro de 2016 e janeiro de 2017, a exposição, pensada para um único lugar ganhou o mundo, esteve em Barcelona, em Buenos Aires, de junho a agosto, em São Paulo, de outubro de 2017 a janeiro de 2018, seguindo para Cidade do México e Montreal. Para Didi-Huberman, as "sublevaciones están en todas partes, todo el tempo". O termo Soulevementsamplia-se com possibilidades e variações de tradução: insurgir, sublevar, provocar, elevar a uma determinada altura, excitar. Podemos optar também por levantes ou revoltas. A exposição no Brasil ganhou o nome de Levantes.

Mas o que a exposição tem a ver com esses levantes e manifestações que iniciamos falando? Elas têm um comum em comum (HARDT; NEDRI, 2014, 2016), uma forma e funções que colocam em deslocamento movimentos e gestos de resistência. Didi-Huberman, na apresentação da exposição, escreve que os levantes/revoltas/ocupações/manifestações transformam nossa imobilidade em movimento, o abatimento em energia, a submissão em revolta, à desistência em alegria expansiva. São gestos, como o dançar dos vagalumes nas noites escuras, gestos onde os braços se levantam, onde os corações pulsam mais forte, onde o corpo se agita, se desdobra, se inquieta e a boca grita e se desata.

Hardt e Negri (2014, p. 138) falam que as manifestações, até esse outrora-agora, permite que nos livremos "das subjetividades empobrecidas produzidas e continuamente reproduzidas pela sociedade capitalista". Um gesto de recusa a essas subjetividades produz um rasgo no tecido social, e os levantes, manifestações, "a rebelião, a revolta não ativam somente uma recusa, mas também um processo criativo", pois ao montarmos uma outra forma, darmos uma outra função ao comum e "ao subverter e inverter as subjetividades empobrecidas da sociedade capitalista contemporânea, descobrem algumas bases reais de nosso poder relativo à ação social e política" (HARDT; NEGRI, 2014, p. 139).

O que produz levantes, movimentos, manifestações, revoltas são forças (DIDIHUBERMAN, 2017, p. 83). O que produz deslocamento e mudança é a força de nossas memória com a força de nosso desejo quando se inflama "las imagens, por su parte, se 
encargan de hacer arder los deseos a partir de las memorias, nuestros recuerdos hundidos en los deseos" (DIDI-HUBERMAN, 2017, p. 88). Esses desejos criam gestos que sobrevivem na memória. A exposição Levantes faz um traçado histórico de gestos que sobrevivem, que afirma ainda uma subjetividade não empobrecida, que recorda, não apenas 2009, 2011 ou 2013. Mas uma luta de um comum, que se faz comum, permanentemente de um desejo de transformação, e não deixar que capitalização do desejo pelo neoliberalismo apague esses gestos e memórias, como diz Safatle (2015, p. 13) "o poder fará tudo para que os livros continuem fechados", e no caso da exposição, o poder fará tudo para que as imagens e as memórias das manifestações, revoltas e levantes, continuem na invisibilidade.

Didi-Huberman monta essa exposição pensando em cinco tempos, cinco gestos que vão do micro ao macro. Fazemos aqui um breve traçado pelos elementos da exposição, para posteriormente apresentarmos o conceito de montagem. $\mathrm{O}$ primeiro gesto, da exposição Levantes, aparece como elementos em fúria, inquietos, que se desencadeiam em outro. A energia se levanta e aquece os espaços de mobilização, é a imaginação que move a movimentos impossíveis. Como podemos ver no drapeado de Man Ray ${ }^{3}$.

\footnotetext{
${ }^{3}$ No catalogo online da exposição Soulevements no Jeu de Paume se pode acessar as imagens contidas aqui. Entrando na aba "Parcours" se acessa uma pequena referência das obras, com sua história e condições de criação. Para acessar: http://soulevements.jeudepaume.org/parcours/.
} 


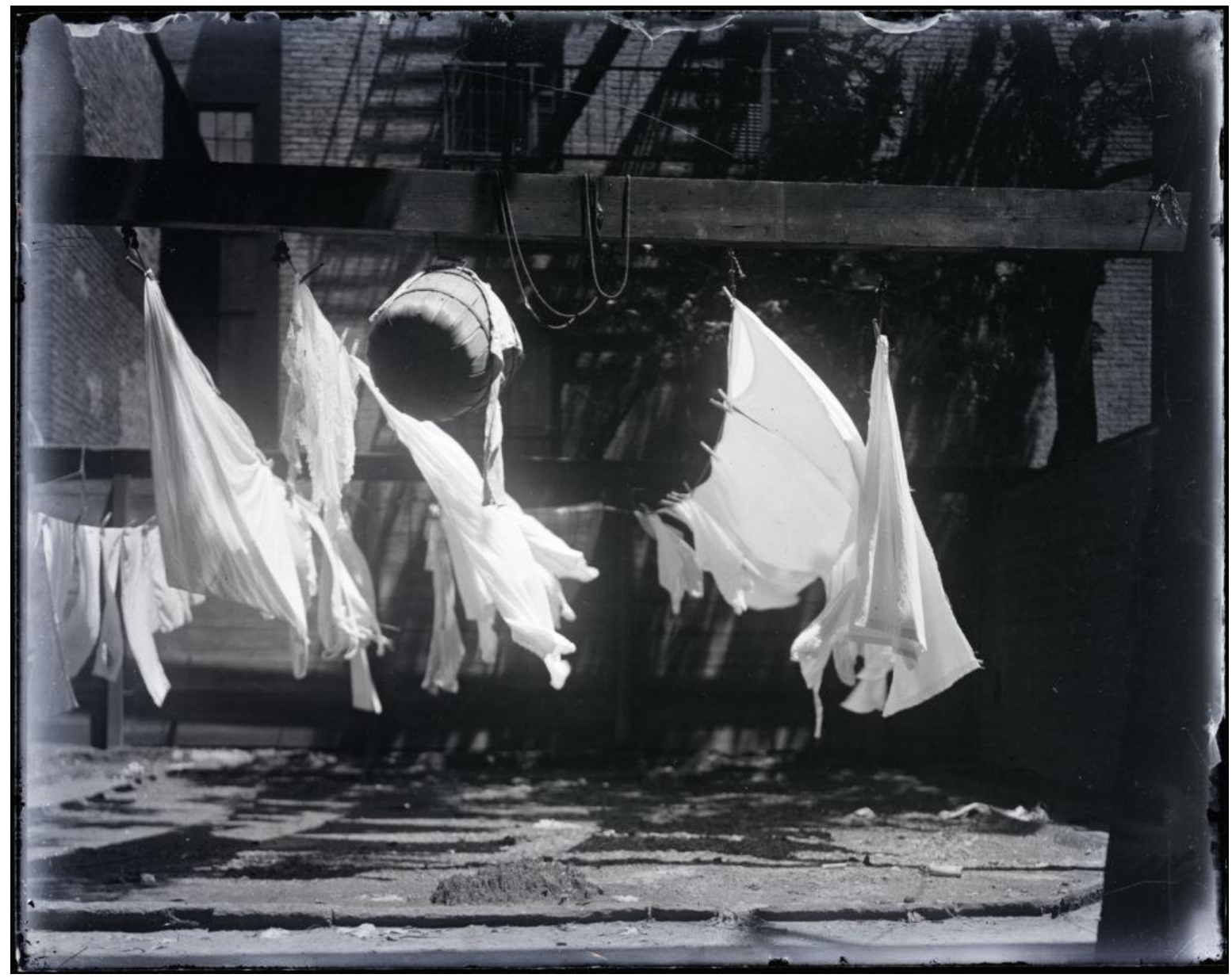

Man Ray, Sculpture mouvante ou La France, 1920 Musée national d'Art moderne, Centre Pompidou, Paris, dation en 1994. (Man Ray Trust / ADAGP, Paris, 2016 / Photo @Centre Pompidou, MNAM-CCI, Dist. RMNGrand Palais / image Centre Pompidou, MNAM-CCI. Disponível no catalogo online da exposição Soulevements.

O segundo gesto é o intensivo, quando o corpo grita não! É de um gesto simples, de uma simples palavra que a ação brota. Levantar o braço. Dizer não! Um gesto que é emoção. Sinal de esperança e resistência. Gestos das bocas de Graciela Sacco e da fotografia dos manifestantes de Gilles Caron. 


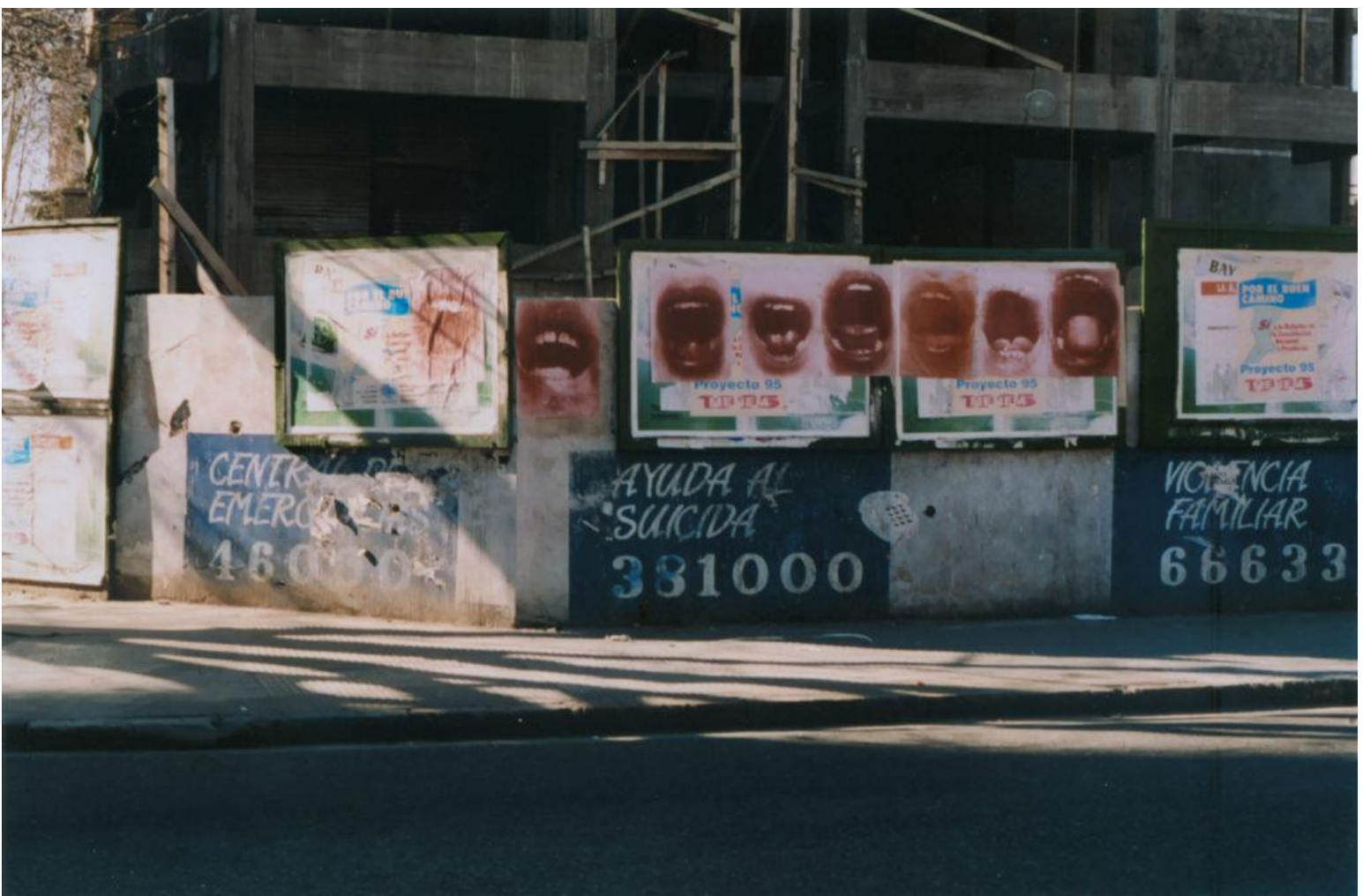

Graciela SACCO, de la serie Bocanada (A breath of fresh air), 1992-1993, posters en las calles de Rosario, Argentina. (Graciela Sacco.Disponível no catalogo online da exposição Soulevements.

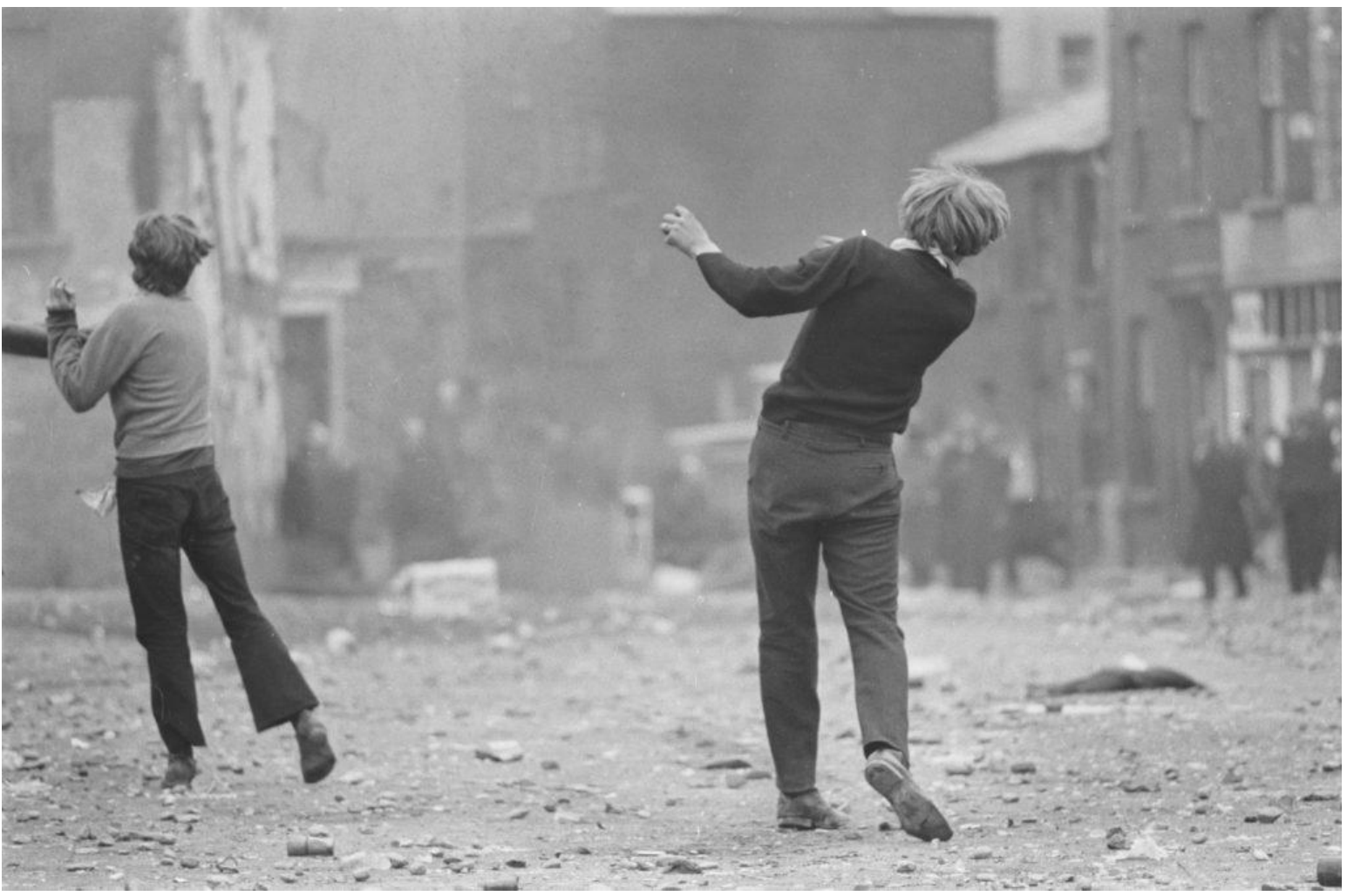

Gilles Caron. Manifestantes católicos, Batalla de Bogside, Derry, Irlanda del Norte, agosto 1969. @Gilles Caron/Fondation Gilles Caron /Gamma Rapho. Disponível no catalogo online da exposição Soulevement. 
O terceiro gesto com o clamor da palavra, ou a palavra exclamada, quando o não se articula em palavras, em frases para contar, cantar, berrar, gritar, discutir, transmitir. Protestos que ganham vozes no panfleto, no lambe-lambe, nas redes sociais, como os cartazes de Raymond Hains nas ruas de Paris.

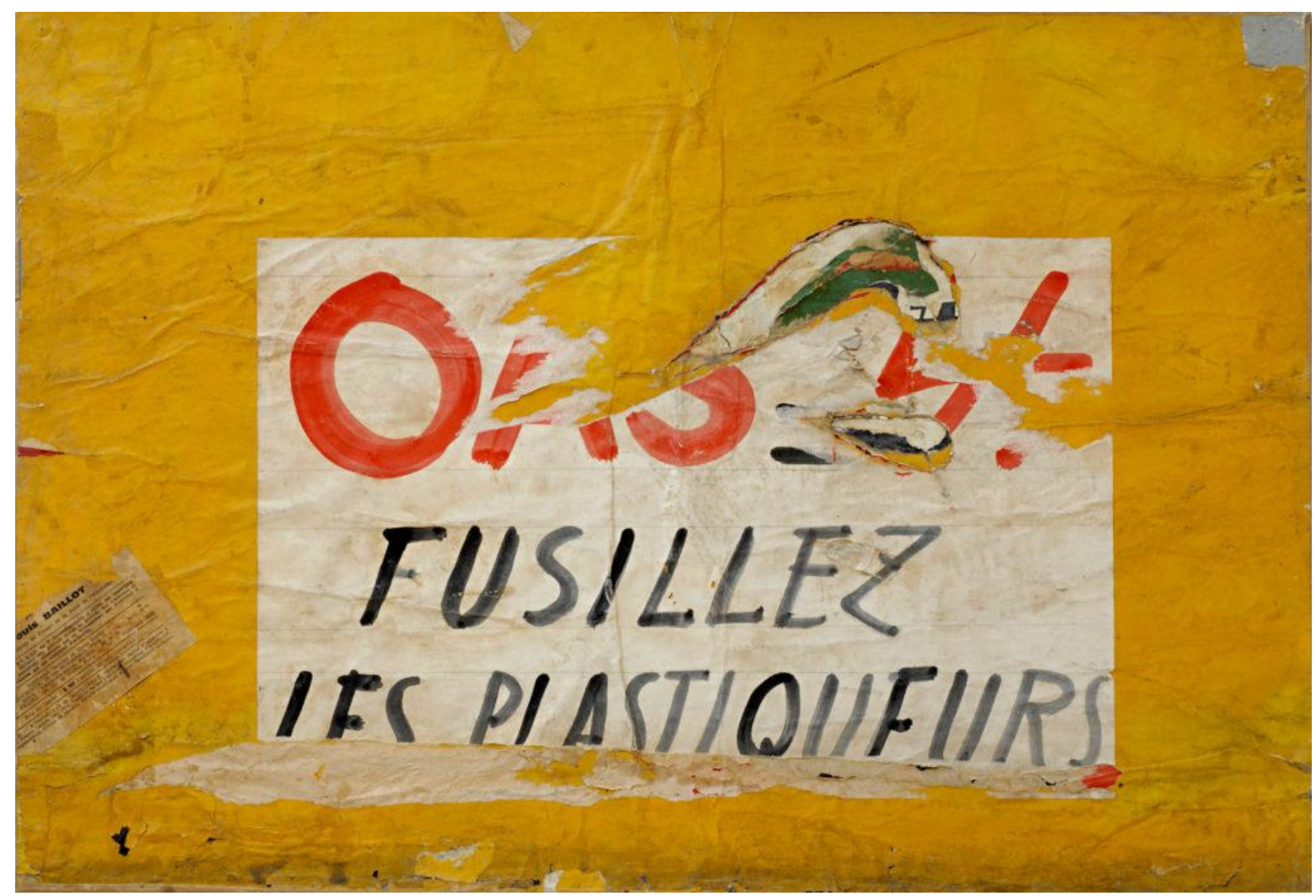

Raymond Hains, OAS. Fusillez les plastiqueurs, 1961 Collection particulière @ C ADAGP, Paris, 2016 / Photo: Michel Marcuzzi. Disponível no catalogo online da exposição Soulevement.

O gesto seguinte é onde os vagalumes se juntam e os conflitos se inflamam, quando levantar barricadas se faz necessário e quando a violência é inevitável. Caos. Resistência. Maneiras e modos de viver juntos são criados. Pedaços. Fragmentos. Estilhaços. De vidro. De bomba. De vidas. Como as barricadas de Paris na insurreição popular de junho de 1848 . 


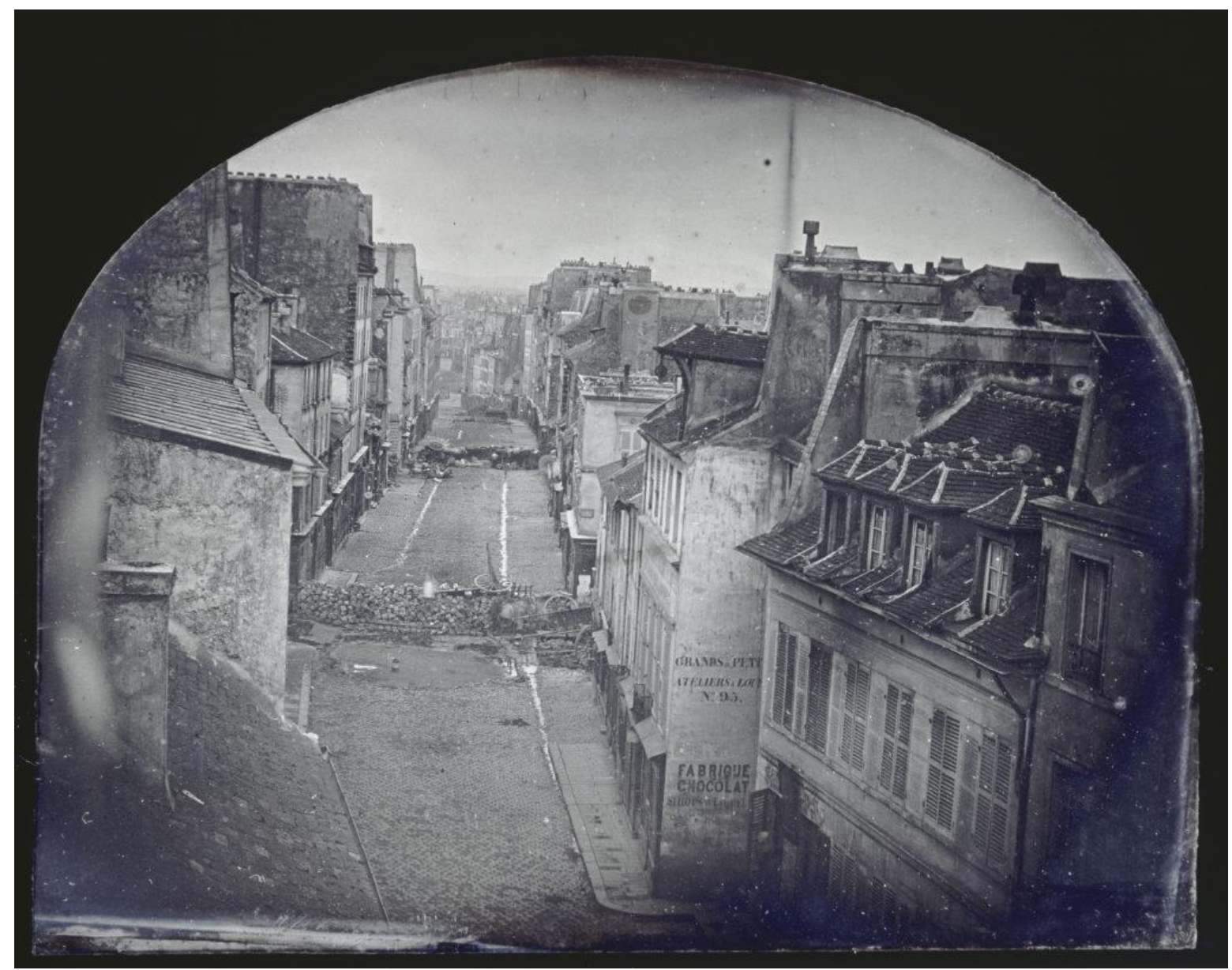

Thibault, La Barricade de la rue Saint-MaurPopincourt avant l'attaque par les troupes du général Lamoricière, le dimanche 25 juin 1848 Musée d'Orsay, Paris Photo (C) RMN-Grand Palais (musée d'Orsay) / Hervé Lewandowski. Disponível no catalogo online da exposição Soulevement.

Por fim, o desejo que é indestrutível, quando os levantes, manifestações, ocupações sobrevivem para além do seu desaparecimento. Pode-se acabar em lágrimas, em corpos mutilados, mas o desejo ainda permanecerá vivo, se não nesses que lutaram e resistiram, nos que virão logo a seguir. O desejo é o que mantém vivo, mantém os pequenos pontos luminosos no escuro da noite. Como a corajosa fotografia de um membro do Sonderkommando de Auschwitz-Birkenau que registrou os únicos testemunhos visuais da asfixia por meio de gás, e uma própria testemunha do perigo, de capturar o que acontecia em Birkenau. 


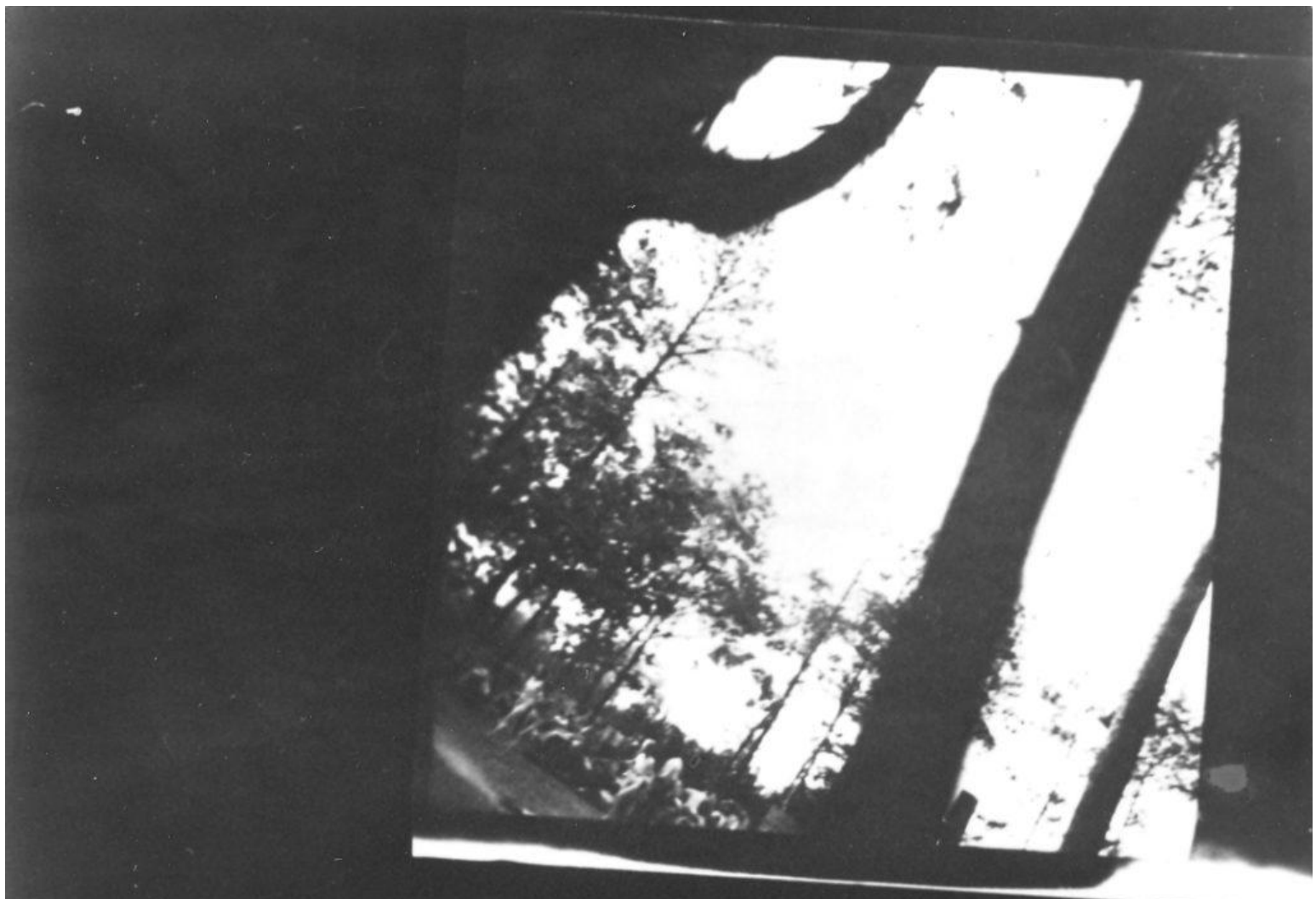

Anonyme (membre du Sonderkommando d'Auschwitz-Birkenau), Femmes poussées vers la chambre à gaz du crématoire V de Birkenau, 1944 Archival collection of the State Museum Auschwitz-Birkrenau, Oświęcim Ph to: Archival collection of the State Museum AuschwitzBirkrenau, Oświęcim. Disponível no catalogo online da exposição Soulevement.

Para Agamben (2009, p.64) vivemos, no contemporâneo, no escuro de nosso tempo. Para ele, "contemporâneo é aquele que recebe em pleno rosto o facho de trevas que provém do seu tempo". Mas que não devemos temermas sim manter "fixo o olhar no escuro de nossa época” (AGAMBEN, 2009, p.65), perceber que mesmo nesse escuro uma luz se dirige a nós. Uma imagem que brilha, que arde, "e a imagem arde no seu contato com o real...Arde pelo desejo que a anima, pela intencionalidade que a estrutura, pela enunciação ... Arde pela destruição... Arde pelo intempestivo movimento... Arde pela sua audácia..." (DIDIHUBERMAN, 2012b, p.208-210). Arde como possibilidade de criação de novos mundos.

É na noite mais profunda, nesse escuro de nosso tempo, que somos capazes de "captar o mínimo clarão ... ainda que tênue" (DIDI-HUBERMAN, 2011, p.30). Didi-Huberman nos presenteia nessa exposição as pequenas luzes, que mostram a sobrevivência, "são apenas lampejos passeando nas trevas" (DIDI-HUBERMAN, 2011, p.84). Assim como os lampejos das ocupações, acontecidas no final do ano de 2016, que somaram mais de 1300 escolas e mais de 190 universidades, são pontos luminosos, de latência, lampejos de desejos possíveis. 
Dessa forma, pode-se dizer aqui, que imagem não é um horizonte, mas imagem é o que manifesta seu "potencial utópico nas suas latências" (DIDI-HUBERMAN, 2010, p.22), no que arde, no que vibra, no que lampeja, no que resta, no que escoa e vaza, no que resiste. Nos gestos enfurecidos, inquietos, intempestivos, que clamam pela palavra, que resistem na violência necessária, que deseja. A "imagem nos oferece algo próximo a lampejos (lucciole)" (DIDI-HUBERMAN, 2011, p.85).

Trata-se de imagem como um instante utópico que cria lacunas, que é frágil e em alguns momentos pode desaparecer: "a imagem se caracteriza por sua intermitência, sua fragilidade, seu intervalo de aparições, de desaparecimentos, de reaparições e de redesaparecimentos incessantes" (DIDI-HUBERMAN, 2011, p.86). A imagem é feita de tudo: tem uma natureza de amálgama, de impureza, de coisas visíveis misturadas com coisas confusas, de coisas enganadoras misturadas com coisas reveladoras, de formas visuais misturadas com pensamento em acto. Por conseguinte, ela não é nem tudo, nem nada. São imagens sobreviventes (DIDI-HUBERMAN, 2012, p.89). Como comenta Didi-Huberman na abertura da exposição em Buenos Aires: Como si inventar imágenes contribuyera - unas veces modestamente, otras con fuerza - a reinventar nuestras esperanzas políticas.

Com isso, mostrar essas imagens da exposição de Didi-Huberaman, é dizer "a imagem", é pensar não importa o que se faça, "há somente imagens, cada imagem é somente compreendida na sua relação com as outras" (DIDI-HUBERMAN, 2006). Ou seja, são "modos de organizar - isto é, também, de desmontar, de analisar, de contestar - o próprio horizonte" (DIDI-HUBERMAN, 2011, p.118).

\section{PARA PENSAR A MONTAGEM}

Nos domínios que tratamos aqui, o conhecimento existe apenas em lampejos. O texto é o trovão que segue ressoando por muito tempo. Benjamin (2009, p. 499).

Colocamo-nos diante de uma imagem para pensar a montagem do pensamento. A imagem é da artista Elida Tessler, de sua obra 'Carta ao Pai'. Uma imagem em 617 fragmentos. E uma imagem em movimento de desconstrução, de desmontagem. 


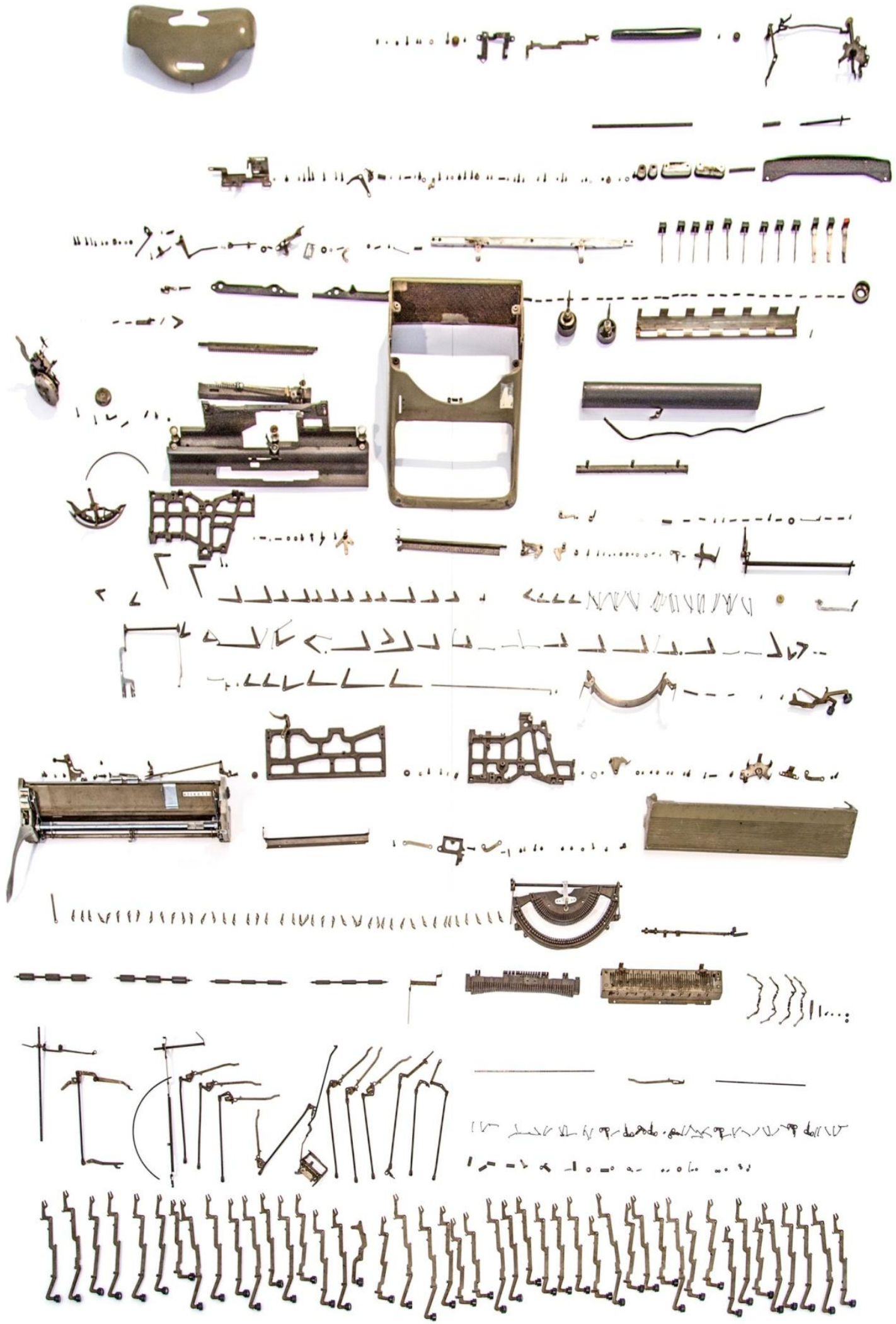

Obra "Carta ao Pai" de Elida Tessler. Imagem cedida pela autora e pela Galeria Bolsa de Arte, onde esteve na exposição “365 dias” de 06/10/15 à 07/11/2015. 
O termo montage, no francês, tem oito significados: levar uma coisa de baixo para cima; ação de por junto elementos constitutivos de um objeto, de um aparelho, de um móvel, para que ele esteja em estado do uso à que se destina; ação de por junto por técnicas apropriadas, elementos (texto, foto, som, imagens etc.) de diversas origens para obter um efeito particular; no cinema, escolha dos diversos elementos que compõem um filme; na eletroacústica, operação destinada à permitir a leitura sem interrupção de gravações inicialmente separadas; na tipografia, composição dos clichês para formar uma página; na mineração, chaminé ou lareira escavada para cima da camada em que se encontram; em usinas, dispositivo de fixação rápida e automática de uma peça em uma máquina-ferramenta.

No português temos sete significados, as diferenças estão no cinema; operação de selecionar, combinar e unir trechos de filmagens em uma sequencia para fazer um filme; no jornalismo e na publicidade a reunião e composição de layout (título, ilustração e texto) de jornal ou revista e o resultado dessa composição; no teatro o ato de encenação; temos outras duas que dizem da ação, processo ou efeito de montar e a colocação e arranjo de pedras ou de outros elementos decorativos no engaste de uma joia. As demais se assemelham a definição do francês.

Didi-Huberman utiliza-se do conceito de montagem a partir dos estudos do AtlasMnenosyne de Aby Warburg; dos escritos fragmentários, do colecionismo e da montagem em Walter Benjamin; dos textos e das colagens de Brecht e do movimento imágetico proporcionado no cinema por Godard e Eisentein. Georges discute a montagem enquanto procedimento filosófico; princípio e criação artística e gesto político. Em uma entrevista de 2007, ao falar sobre a imagem, comenta que a imagem é o que dura apenas um instante, um instante momentâneo, um instante qualquer. "Eso es la imagem. La imagem es una mariposa. Una imagem es algo que vive y que sólo nos mestra su capacidade de verdade en un destello (instante)"

Ao desfragmentarmos, desmontarmos a leitura, a escrita e o pensamento, como a máquina de Elida Tessler, temos a liberdade de modificar a sua configuração. Podemos criar pilhas, montes, constelações, podemos abrir novas analogias, novos trajetos no pensamento. Ao cortar o pensamento, ao fragmentar a escrita, ao colocar-se na experiência de monta-los, podemos observar melhor os sintomas do presente e abrir frestas e possibilidades de pensar e escrever diferentemente (DIDI-HUBERMAN, 2010a). 
É de "montagem ou de re-montagem que se deve falar" (DIDI-HUBERMAN, 2015, p.132-133), pois, enquanto procedimento, a montagem supõe a desmontagem. Para criar a obra "Carta ao Pai", Elida Tessler teve que desmontar, criar fragmentos. Didi-Huberman utiliza a montagem como um deslocamento, como uma descontinuidade no tempo e no pensamento.

A montagem é um modo de expor visualmente as descontinuidades do tempo que atuam em todas as sequências da história. (...) Aqui, portanto, "montar imagens" nunca decorre de um artifício narrativo para unificar fenômenos dispersos, mas, ao contrário, de um utensílio dialético no qual se cinde a aparente unidade das tradições figurativas no Ocidente. (DIDI-HUBERMAN, 2013a, p.399-400).

A montagem é um procedimento, e necessita da desmontagem para funcionar, ou seja, para que exista montagem de algo é necessário que exista também sua desmontagem. Desmontamos o pensamento com imagens e palavras sobre as manifestações de um outroraagora para chegar na exposição de Didi-Huberman que nos remete ao conceito de Montagem. Existe um percurso para chegar onde queremos, que veremos logo a seguir, e para entendermos essa imagem precisamos desmontar, no caso desse ensaio, através de uma olhar sobre os acontecimentos de agora, sobre os acontecimentos de outrora com a exposição, remontarmos o texto para entender o conceito de montagem, e finalizamos com a desmontagem do neossujeito.

A montagem é um procedimento que permite um processo de interrupção sendo possível sobrepor partes distintas. "A montagem talha as coisas habitualmente reunidas e conecta as coisas habitualmente separadas ... As coisas exteriores não são mais familiares, elas se deslocam. Qualquer coisa ali se tornou muito leve, que vai e vem" (DIDIHUBERMAN, 2016, p.6). É esse deslocamento de um espaço para outro, de uma temporalidade para outra. Um anacronismo. Brech com tesoura e cola cortava as imagens de jornais e revistas para reorganiza-las em uma outra ordem de legibilidade (HONESKO, 2011). Podemos encontrar formas de pensar por montagem em Aby Waburg, March Broch, Walter Benjamim, Sergei Eisenstein, Carl Eisntein, André Marlaux, George Bataille, George Simmel, Franz Kafka, Marcel Proust, Igor Stravisnky. Didi-Huberman (2007) comenta que esses autores operam como um verdadeiro pensamento por montagem "(así lo llamo yo conocimiento por el montaje) assim chamo eu - um conhecimento por montagem". Para DidiHuberman a montagem é um método, um procedimento moderno de conhecimento.

O conhecimento por montagem parte das diferenças, da conexão de fragmentos, de intervalos e instantes quaisquer sem buscar a totalidade, a universalidade, a unidade. Separa o 
que está reunido e conecta o que está habitualmente separado (JACQUES, 2015). A ideia de montagem não parte de "ideias já dadas, de nexos prontos ao contrário, busca encontrar possíveis nexos ainda não conhecidos durante a própria prática (exercício ou jogo) da montagem" (Ibid., p. 69). Monta-se criando nexos de sentidos.

Entendemos, com Didi-Huberman (2015), que a montagem se debruça para olhar como se dá a relação entre as coisas. Esse procedimento funciona desnaturalizando o olhar para funcionar com o conhecimento por desmontagem e remontagem, problematizando a perspectiva da representação e do sujeito. Para o autor, a montagem é a arte de produzir esta forma que pensa a diferença. Montagem, então, como uma aproximação e uma transgressão das fronteiras disciplinares, como uma potencialização e não como um empobrecimento relembrando aqui as subjetividades empobrecidas de Hardt e Negri, e a pobreza da experiência de Walter Benjamin.

Essa diferenciação da montagem pode ser entendida como um processo de singularização, ou seja, uma "montagem das singularidades". Cabe lembrar que a montagem não apressa a conclusão de nada e nem fecha ou enclausura. A montagem abre as possibilidades e não a "esquematiza abusivamente. Quando nos permite aceder às singularidades do tempo e, por conseguinte, à sua multiplicidade essencial" (DIDIHUBERMAN, 2012, 156). A montagem, assim, pode ser tomada como uma escuta flutuante, atenta às redes de detalhes, as tramas sensíveis formadas pelas relações entre as coisas, os trapos, restos e fragmentos.

Didi-Huberman trabalha a montagem como procedimento de remontagem, que se ocupa dos trapos, dos pormenores que dão legibilidade a um conjunto de pensamento que desloca e inquieta o pensamento. Montamos o pensamento colando nossas coleções de palavras (lidas, ouvidas, roubadas, pensadas, traduzidas). Somos montados por discursos que nos atravessam, e são atemporais, um certo anacronismo das palavras e do pensamento. Georges opera com o pensamento por montagem como procedimento filosófico, gesto politico e criação artística e "talvez ele defenda tanto a montagem pois é - como de certa feita todos nós somos - feito a partir dela. Todos somos montagens de imagens, textos experiências" (CAMPOS, 2017, p. 287). 


\section{DE UMA MONTAGEM DO AGORA-OUTRORA: A DESMONTAGEM DO NEOSSUJEITO}

Queremos terminar esse ensaio com uma a montagem, e a desmontagem, de uma ideia. O empobrecimento da subjetividade, uma das consequências do neoliberalismo, produz para Dardot e Laval (2016), o neossujeito. Os autores compreendem o neoliberalismo como "mais que um mero sistema econômico de organização de trocas, mas também como um dispositivo no qual está inserido um processo específico de subjetivação baseado na compreensão de si como uma empresa e dos outros como potenciais concorrentes" (DARDOT; LAVAL, 2016, p. 327).

O neossujeito, o sujeito neoliberal em formação, para Dardot e Laval (2016, p. 231) é a uma montagem de subjetivações de "desempenho e gozo", de um dispositivo de eficácia para a produção maior da felicidade, "a lei da eficácia é intensificar os esforços e os resultados e minimizar os gastos inúteis" (ibid., p. 325). O desejo é alvo do novo poder. Desejo de ser feliz, de ser melhor, de escrever melhor, de ganhar mais, de produzir mais, trata-se então, nessa nova montagem subjetiva que vivemos, "de governar um ser cuja subjetividade deve estar inteiramente envolvida na atividade que se exige que ele cumpra. Para isso, deve se reconhecer nele a parte irredutível do desejo que o constitui” (ibid., p. 327).

Dardot e Laval (2016) chamam essa gestão moderna do desejo de um "governo lacaniano" para dizer que o ser desejante, não é apenas onde se aplica o poder, mas sim onde se dirige as condutas. Ser neossujeito é ser empresário de si mesmo, a nova subjetividade posta em cena é do governamento de si como uma empresa, ou seja, fazer da própria vida uma empresa. Desenvolver os modos de vida com essa racionalidade produz uma serie de “diagnósticos clínicos do neossujeito", apontados também por Safatle (2015), através do desempenho e da superação de si mesmo, para produzir mais, de um certo "gozo de si", o sofrimento no processo de trabalho, a corrosão da personalidade, a desmoralização, a depressão generalizada, apontados por Dardot e Laval, produzem dois rostos, "o rosto triunfante do sucesso sem pudor e o rosto deprimido do fracasso diante dos processos incontroláveis e das técnicas de normalização" (DARDOT; LAVAL, 2016. p. 374).

O que trazemos, de forma extremamente resumida, é que o neoliberalismo está produzindo formas de vida capturadas pelo desejo em uma forma de objetificação, pois "não se trata simplesmente de transformar o outro em coisa $[\ldots]$ mas de não poder mais conceder 
ao outro, nem a sim mesmo enquanto outro, nada além de seu valor de gozo, isto é, sua capacidade de render um plus" (DARDOT; LAVAL, 2016, p. 371). O neossujeito, nessa montagem, é condenado a "mestre de desempenhos admiráveis e objeto de gozo descartável" (ibid., p. 374).

Esse processo de montagem de subjetivações tem como produto o individualismo que não permite a produção de um comum como qualidade de um projeto de multidão, como faísca de mudanças e possíveis levantes. Comum entendido na concepção de Hardt e Negri (2016, p. 74) "como o poder da vida de resistir e determinar uma produção alternativa de subjetividade". Mas o que fazer diante de tal captura do desejo? De tal montagem de subjetividade? Nesse escuro de nosso tempo - lembrando Agamben?

Safatle $(2015$, p. 16) comenta que se quisermos mudar "será necessário começar a se perguntar como podemos ser afetados de outra forma, será necessário estar disposto a ser individualizado de outra maneira, a forçar a produção de outros círculos". Hardt e Ngri (2014, p. 138) apontam que os movimentos "estão criando novas subjetividades, que desejam e são capazes de relações democráticas. Os movimentos estão redigindo um manual de como criar e viver numa nova sociedade”. Dardot e Laval (2016, p. 402) dizem que cabe a nós permitir um novo sentido e abrir novos caminhos, "o governo dos homens pode alinhar-se a outros horizontes, além daqueles da maximização do desempenho, da produção ilimitada, do controle generalizado". Cabe uma outra montagem de relações, e como diz as últimas linhas de Dardot e Laval, "as práticas de comunização do saber, de assistência mútua, de trabalho cooperativo podem indicar os traços de outra razão do mundo" (ibid., p. 472).

O Neossujeito é montado em uma forma de empobrecimento subjetivo, de captura do desejo. Pensamos aqui, finalizando essa escrita, que podemos ainda pensar em um comum, existe ainda a possibilidade de montagem de outros comuns, através da memória dos levantes e manifestações, de gestos, por mais micro que sejam, resistir. Pensar o comum, ou os gestos de resistência a montagem do neossujeito, é produzir novos modos de existência que passem por uma função Política, Estética e Ética.

Fazer a montagem de um agora-outrora com: a) uma função teórica, um jeito de pensar, de apropriação dos gestos e da memória conhecendo o que se tem produzido; b) uma função prática menor, como um jeito de fazer micropolítico; c) uma função de montagem, um jeito de escrever e narrar a experiência para fazer aparecer os gestos que resistem. "Tiempos oscuros. Pero qué hacemos cuando reina la obscuridad?” (DIDI-HUBERMAN, 2017, p. 21). 
Mostramos a força dos levantes para fazer um gesto de não esquecimento, um gesto para sair do empobrecimento e da captura do desejo pelo neoliberalismo. Um gesto de mostrar o comum porque "no se acaba nunca de aprender, de descubrir, de inventar nuevos montajes capazes de hacer que nazcan nuevas emociones y de encontrar nuevos paradigmas para el pensamiento" (DIDI-HUBERMAN, 2017, p. 25).

\section{REFERÊNCIAS}

AGAMBEN, G. O que é contemporâneo? e outros ensaios. Trad. Vinícius Nicastro Honesko. Chapecó, SC: Argos, 2009.

BAUMAN, Zygmunt. Estado de Crise. Rio de Janeiro: Jahar, 2016.

BENJAMIN, W. Passagens. Belo Horizonte: Editora UFMG, São Paulo: Imprensa Oficial do Estado de São Paulo, 2009.

CAMPOS, Daniela Queiroz. Um saber montado: Georges Didi-Huberman a montar imagem e tempo. Aniki : Revista Portuguesa da Imagem em Movimento, América do Norte, 4, mai. 2017, p.269288. Disponível em: 〈http://aim.org.pt/ojs/index.php/revista/article/view/299>. Acesso em: 01 Ago. 2017.

DARDOT, Pierre; LAVAL, Christian. A nova razão biopolítica: ensaio sobre a sociedade neoliberal. São Paulo: Boitempo, 2016.

DELEUZE, G.; PARNET, C. O abecedário de Gilles Deleuze. Entrevista com Gilles Deleuze. Editoração: Brasil, Ministério da Educação, "TV Escola”, 2001.

DELEUZE, G. Cinema 1. A imagem-movimento. São Paulo: Brasiliense, 1985. . Cinema 2. A Imagem-Tempo. São Paulo: Brasiliense, 2007. .Cine I: Bergson y las Imágenes. Buenos Aires: Cactus, 2009.

DIDI-HUBERMAN, G. Atlas: como levar o mundo nas costas?. Trad. de Alexandre Nodari. Sopro, n.41, dezembro de 2010a, disponível em <http://www.culturaebarbarie.org/sopro/n41.html>. A imanência estética. ALEA. vol. 5, n. 1, jun/jul, 2003. . A Imagem Sobrevivente: história da arte e tempo dos fantasmas segundo Aby Warburg. Rio de Janeiro: Contraponto, $2013 \mathrm{~b}$. . A Pintura Encarnada. São Paulo: Escuta, 2012c. . A Sobrevivência dos Vaga-Lumes. Belo Horizonte: Editora UFMG, 2011. . Cascas. São Paulo: Revista Serrote, 2013a.

. Diante da Imagem: questões colocada aos fins de uma história da arte. São Paulo: Editora 34, 2013c. 
Diante do Tempo: História da Arte e anacronismo das imagens. Belo Horizonte: Editora UFMG, 2015.

Imagens Apesar de Tudo. Lisboa: KKYM, 2012.

. O que vemos, O que nos olha. São Paulo: Editora 34, 2010.

Quando as imagens tocam o real. PÓS: Revista do Programa do Pós-Graduação em Artes da escola de Belas Artes da UFMG, vol.2, n.4, nov. 2012b, p. 204-219. Texto disponível em http://www.eba.ufmg.br/revistapos/index.php/pos/article/view/60.

Remontar, remontagem (do tempo). Caderno n. 47. Belo Horizonte: Chão da Feira, 2016.

Ser crânio: lugar, contato, pensamento, escultura. Belo Horizonte: C/Arte, 2009.

S’inquiéter devant chaque image. (entrevista com Georges Didi-Huberman realizada por Mathieu Potte-Bonneville e Pierre Zaoui), in Vacarme, n³7, outono de 2006. Disponível em: http://www.vacarme.org/article1210.html

Sublevaciones. Sáenz Peña: Universidade de Tres de Febrero, 2017.

Un conocimiento por el montaje. Entrevista a Pedro G. Romero. Revista Minerva n. 05.

Madrid. 2007. Disponível em: http://www.circulobellasartes.com/revistaminerva/articulo.php?id=141

FOUCAULT, Michel. Conversa com Michel Foucault. In: FOUCAULT, Michel. Repensar a política. Rio de Janeiro: Forense Universitária, 2010, (Ditos \& escritos VI). p. 289-347.

Eu sou um pirotécnico. In: POL-DROIT, Roger. Michel Foucault, entrevistas. São Paulo: Graal, 2006, p. 67-100. O que é um autor? In: Estética: literatura e pintura, música e cinema. Ditos \& escritos III. Rio de Janeiro: Forense Universitária, 2001b. p. 264-298.

HARDT, Michael; NEGRI, Antonio. Bem Estar Comum. Rio de Janeiro: Record, 2016. Declaração Isto não é um manifesto. São Paulo: n-1 edições, 2014.

HONESKO, Vinicius. Mãos ao alto: olhos armados. Sopro: panfleto político-cultural, n. 56, p. 2-10, 2011.

JACQUES, P. B. Montagem Urbana: Uma forma de conhecimento das cidades e do Urbanismo. IN: JAQUES, Paola Berenstein; BRITTO, Fabiana Dultra (org). Experiências metodológicas para compreensão da complexidade da cidade contemporânea. Salvador: EDUFBA, 2015. p. 47-94.

SAFATLE, Vladimir. O circulo dos Afetos. São Paulo: Cosac Naify, 2015.

SCHULER, Betina. Por entre escritas, leituras e cadeiras: O Procedimento genealógico e o cuidado de si. IN: SHULER, Betina; MATOS, Sônia Regina da Luz; CORAZZA, Sandra Mara (Orgs). Cadernos de notas 6: Experimentações de escrita, leitura e imagem na escola. Porto Alegre: UFRGS, Doisa, 2014. 
VELLOSO, Rita. O tempo do agota da insurgência: Memória de gestos e política do espaço, segundo Walter Benjamin. In: BRITTO, Fabiana Dultra; JACQUES, Paola Berenstein (org). Corpocidade: Gestos Urbanos. Salvador: Edufba, 2017. Pg 42-69. 